\title{
Methodology for the Improvement of Large District Heating Networks
}

\author{
Anna Volkova ${ }^{1}$, Vladislav Mashatin ${ }^{2}$, Aleksander Hlebnikov ${ }^{3}$, Andres Siirde ${ }^{4},{ }^{1-4}$ Department of Thermal \\ Engineering, Tallinn University of Technology
}

\begin{abstract}
The purpose of this paper is to offer a methodology for the evaluation of large district heating networks. The methodology includes an analysis of heat generation and distribution based on the models created in the TERMIS and EnergyPro software Data from the large-scale Tallinn district heating system was used for the approbation of the proposed methodology as a basis of the case study. The effective operation of the district heating system, both at the stage of heat generation and heat distribution, can reduce the cost of heat supplied to the consumers. It can become an important factor for increasing the number of district heating consumers and demand for the heat load, which in turn will allow installing new cogeneration plants, using renewable energy sources and heat pump technologies.
\end{abstract}

Keywords - cogeneration, district heating, energy efficiency, energy systems, pipes, simulation

\section{INTRODUCTION}

Properly operating district heating systems can provide improvement in energy efficiency, reduce emissions, improve energy security and competitiveness and creating of new jobs. A district heating network includes the infrastructure for centralized heat production and distribution to the consumers for providing space heating and hot tap water in a wider area. The district heating system can be considered energy efficient and cost-effective only at optimal operation conditions and minimum heat loss.

One of the actions mentioned in the European Union (EU) strategy Energy 2020 is to increase the uptake of high efficiency district heating systems. A high efficiency district heating system can only be provided when efforts are concentrated on the whole energy chain, from energy production, via distribution, to final consumption [1].

There are more than 5000 district heating systems in Europe, currently supplying more than $9 \%$ of total European heat demand. District heating systems are mainly used in the northern European countries, such as Sweden and Finland [2]. As regards to Latvia, Lithuania and Estonia, the percentage of district-heated households is around $60-75 \%$.

The main advantages of district heating are efficiency and reliability compared to the individual heating systems. Efficiency can be reached when heat is produced simultaneously with electricity in the cogeneration process. More options of flue gas cleaning are available for larger heat generation units than for small scale boilers. District heating is a good solution for the areas with high population density and multiple dwelling houses, because the investments per household can be reduced. Due to the fact that the connection to a single-family house is rather expensive, district heating is a less attractive solution for the countryside.

Large district heating networks supply heat usually in big cities, since the level of heat consumption in large areas is high. Large district heating systems are typical for Estonia. District heating is used in all bigger cities in Estonia, including the capital Tallinn [3].

The purpose of this paper is to offer a methodology for the improvement of large district heating networks. For the approbation of the offered methodology, the data on the Tallinn district heating system was used as a basis of the case study.

District heating systems offer a potential for renewable heat generation technologies. The most popular renewable energy source for heat generation is biomass, which includes agricultural, forest, and manure residues and to an extent, urban and industrial wastes, which under controlled burning conditions, can generate energy, with limited environmental impacts [4-6]. Geothermal sources as renewable energy can be used for district heating system and geothermal district heating has been given increasing attention in many countries during the last decade [7]. The expansion of district heating will help utilize heat production from the above mentioned renewable energy sources [8].

The developed district heating systems promote cogeneration development. When a cogeneration plant supplies heat to the district heating system, its capacity is defined by maximum heat load of this system $[9,10]$. In some cases, a thermal storage unit is attached to the cogeneration plant for efficient operation of the district heating system [11]. The cogeneration plant with district heating provides an alternative energy production and delivery mechanism that is less resource intensive, more efficient and provides greater energy security than many popular alternatives [12].

\section{Methodology}

As it was mentioned before, only an optimally operated district heating system can be considered energy efficient. The efficiency of operation should be evaluated both relative to heat generation (boiler houses and cogeneration plants) and heat distribution networks (pre-insulated pipes).

\section{A. Evaluation and improvement of heat distribution}

The improvement of a district heating network is a complex task where many parameters should be taken into account. There are three ways to improve a district heating system by 
reducing the heat loss - the low, medium and high investment scenarios as described in the following paragraphs.

The low investment scenario assumes reduction of supply temperature and increased water flow. This can be possible only in case the network pipe dimensions are larger than required. In this case the pressure will grow, which means that the number of damaged pipes may increase. The increased pressure can also be a problem for the customer systems. Additional pumping capacity is required in power plants.

The medium investment scenario assumes replacement of pipe insulation. The insulation can be replaced when the steel casing of pipe is in good condition, otherwise the pipe should be fully replaced. Selection of insulation thickness is a complex task where many parameters should be taken into account: material and work cost, thermal conductivity of new and old insulation, pipe diameter, environmental temperature, water temperature and so on.

The high investment scenario assumes reconstruction of pipelines with the installation of pre-insulated pipes and increasing or decreasing their diameter, if needed. The new diameter should be selected very carefully, at the same time considering the future network development possibility. As a matter of fact, it is possible to replace all the pipes only in small networks; otherwise the project cost will be too high.

It is not possible to carry out such improvement without creating a virtual model and trying all possible scenarios, especially in large networks where many heat suppliers can work together in different combinations. For the evaluation of heat distribution, a special model was created using the commercial TERMIS software [13]. Simulation can be done using other software like Bently sis HYD or Zulu Thermo, but TERMIS is considered to be the most advanced, powerful and extensive district energy network simulation platform for improving system design and operation. Different types of improvement of European district heating systems were made using commercial TERMIS [13-15]. TERMIS is a hydraulic modeling software tool, which gives an overview and control of district energy network by simulating the flow, pressure and thermal behavior. With TERMIS, it is possible to reduce energy loss and reduce $\mathrm{CO} 2$ emissions [13].

Before creating the model, it is necessary to create a database, which should include the data on all the pipes with their dimension, insulation, coordinates, roughness and single pressure loss description; the consumer data like seasonal consumption of heat and tap water; environmental data like the air temperature for overhead pipelines and soil temperature for subsurface pipelining to calculate the heat loss.

\section{B. Evaluation and improvement of heat production}

Usually in large-scale district heating systems various energy sources are used: large and small boiler houses and cogeneration plants. Both fossil fuel and wood fuel can be used for heat production. The operation efficiency of boiler houses depends on the manufacturing year of the installed equipment. The renovated or new boiler houses have higher efficiency and are easily operated.
As regards cogeneration plants, especially those based on wood fuel, the efficiency begins to fall when the load is less than $70 \%$. Besides, the investments in cogeneration plants operation are much higher than in boiler houses. That is why, it is more important to operate the cogeneration plants at the maximum load. The boiler houses are often used as peak demand covering units.

The following indicators should be used for the evaluation of heat production: type of production unit (boiler house or cogeneration plant), heat capacity (for cogeneration plant the electrical capacity, additionally), age of a heat production unit, fuel type (fossil fuel of renewable fuel), energy efficiency, and shut-downs.

It is important to find the right solution in the operation strategy for all heat production units. Priority should be given to CHP production. Boiler houses are used only in case the heat supplied from a cogeneration plant is insufficient.

Different types of modeling tools for the economic analysis and optimal operation of cogeneration plants have been developed in recent years. As examples SEA/RENUE, CHP sizer, Ready Reckoner, EnergyPro can be mentioned [16]. EnergyPRO was chosen for evaluation of heat production in the district heating system, because it is modeling software which allows carrying out detailed technical and financial analyses of energy projects. For the optimization of cogeneration plants, the priority in EnergyPRO software tool is that the cogeneration plant meets the heat demand for the period being analyzed [17].

A simple model, which was created using the EnergyPro software, can be applied to determine the optimal operating strategy. The current situation and development scenarios can be compared, using the following parameters: heat production, fuel consumption, electricity production, operation time.

\section{CASE Study}

\section{A. Tallinn Municipality District Heating System}

Tallinn is the capital of Estonia located on the northern coast of the country. Tallinn is the largest city in the country with about 415,000 inhabitants.

District heating networks in Estonia are mostly old and in poor condition. The state of the district heating networks of Tallinn is typical for the rest of Estonian district heating systems. In Tallinn the heat is supplied to the consumers through a 429-kilometre long heating network including 119 $\mathrm{km}$ of pre-insulated pipes $(27.7 \%), 22.2 \mathrm{~km}$ is a pipeline with the renovated PUR insulation; $46 \%$ of the whole pipeline network is canal pipes and $8.2 \%$ overhead pipeline. Other pipelines are in tunnels and underground. The diameter of the main pipeline is up to $1200 \mathrm{~mm}$. The peak heat load of the Tallinn district heating system was $640 \mathrm{MW}\left(-22.6^{\circ} \mathrm{C}\right)$ in the $2010 / 2011$ heating season while in the 2009/2010 heating season it was higher reaching $695 \mathrm{MW}\left(-23.4^{\circ} \mathrm{C}\right)$. The minimum heat load during the summer period is $55-65 \mathrm{MW}$ [3]. The district heating systems of Tallinn were mostly constructed in 1960-1980 and their average age is 23 years as of 2012. The district heating systems of Tallinn consist of 


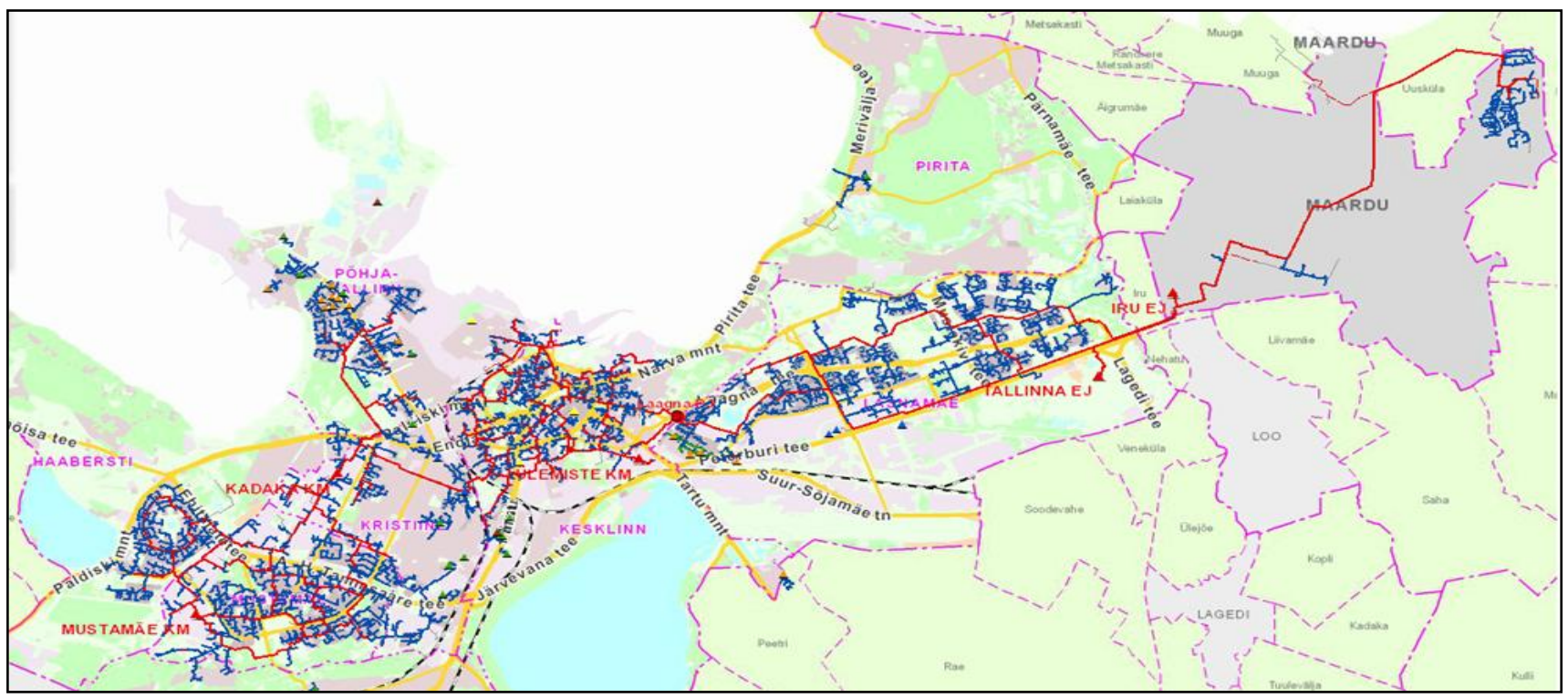

Fig.1. Tallinn district heating network

three connected districts of central heat supply where one of them is divided into two smaller districts, and 26 local boiler houses. Currently two cogeneration plants and three largescale boiler houses supply heat to the districts of Tallinn. Almost the whole district heating network belongs to the Tallinna Küte company [18]. The Tallinn district heating network is shown in Figure 1.

Most of the pipelines were built during the rapid industrial growth of the city and thus the pipelines were oversized with a view of future development. After the collapse of the Soviet Union, however, many industries were closed. At the moment there are two main problems in the network: bad insulation and oversized pipelines; as a result, heat losses are high. According to the Tallinna Küte AS development plans, the relative heat loss should be reduced by $20 \%$.

\section{B. Heat distribution}

\section{Model description}

A model was created for the Tallinn district heating network. The model was designed for 9868 pipes, over 3658 consumers and 9800 nodes with the geographic information included.

Different scenarios were simulated for the hydraulic and heat loss analyses:

- current consumption and temperature schedule;

- current consumption and maximum temperature decrease by $15^{\circ} \mathrm{C}$;

- consumption reduced by $20 \%$ and current temperature schedule;

- consumption reduced by $20 \%$ and maximum temperature decrease by $20^{\circ} \mathrm{C}$.

In the fourth scenario the temperature is decreased by $20^{\circ} \mathrm{C}$ and due to the reduced consumption, the water flow can be increased further. For the heat loss analysis, the average seasonal temperatures were decreased by $10^{\circ} \mathrm{C}$. All scenarios were calculated twice: for the maximum consumption at $-22^{\circ} \mathrm{C}$ to analyze the hydraulics and for the average seasonal parameters to analyze the heat loss.

\section{Input data and assumptions}

All the data has been taken from the Tallinna Küte GIS and converted to fit the TERMIS model. Tallinna Küte also has a large statistical database on different parameters in the critical points and consumption of each household during the last ten years. The parameters in critical points are required for model tuning; the number of points depends on the network. The GIS data and other databases can easily be interconnected by using Model Manager. Depending on the model, the estimated or average seasonal consumption can be used while the average seasonal consumption is more justified in most cases. First simulation can be made when the plant parameters like water flow, pressure and temperature are given. After first simulation with the adjustment factors applied, the simulation results should be identical to the known parameters in critical points. Only in this case the input parameters can be changed and it can be assumed that the simulation result is correct.

\section{$\underline{\text { Results }}$}

The results of model simulation are shown in Table I and Table II. Table I shows the results at the maximum consumption and should be used for hydraulic parameters analysis, the Table II shows the seasonal average results and should be used for heat loss analysis.

TABLE I

SIMULATION RESULTS FOR THE MAXIMUM CONSUMPTION AT $-22^{\circ} \mathrm{C}$

\begin{tabular}{|l|l|l|l|l|}
\hline Outdoor temp. $\mathbf{- 2 2}^{\circ} \mathbf{C}$ & today & $\mathbf{- 1 5}^{\circ} \mathbf{C}$ & $\mathbf{- 2 0 \%}$ & $\mathbf{- 2 0}^{\circ} \mathbf{C} /-20 \%$ \\
\hline Production, MW & 678 & 670 & 558 & 546 \\
\hline Consumption, MW & 600 & 600 & 480 & 480 \\
\hline Heat loss, MW & 78 & 70 & 78 & 66 \\
\hline Heat loss, \% & $11.5 \%$ & $10.4 \%$ & $14.0 \%$ & $12.1 \%$ \\
\hline Water flow, t/h & 11180 & 14070 & 8920 & 11890 \\
\hline
\end{tabular}


As it can be seen in Table II, with changing the yearly average temperature by $10^{\circ} \mathrm{C}$, it is possible to reduce the average relative heat loss for a heating season by $1.1 \%$ points that makes about $23.2 \mathrm{GWh}$ (for the $5800 \mathrm{~h}$ heating season) or over $4200 \mathrm{t} / \mathrm{CO}_{2}$ in case the consumption stays at the same level as today. In case the consumption will be reduced for $20 \%$ in the future, the relative heat loss can be reduced by $1.3 \%$ compared to the current temperature schedule. However, the relative loss would be higher compared with the present consumption. A possible solution in this case the temperature lowering could be higher, especially, as it can be seen, water flow is only $6.5 \%$.

TABLE II

Simulation Results For AVERAge SEASONAL PARAMETERS

\begin{tabular}{|l|l|l|l|l|}
\hline Season average & today & $\mathbf{- 1 0 ^ { \circ } \mathbf { C }}$ & $\mathbf{- 2 0 \%}$ & $\mathbf{- 1 0 ^ { \circ } \mathbf { C } / - 2 0 \%}$ \\
\hline Production, MW & 324 & 320 & 267 & 263 \\
\hline Consumption, MW & 279 & 279 & 223 & 223 \\
\hline Heat loss, MW & 45 & 41 & 44 & 40 \\
\hline Heat loss, \% & $13.9 \%$ & $12.8 \%$ & $16.5 \%$ & $15.2 \%$ \\
\hline Water flow, t/h & 7280 & 9260 & 5800 & 7340 \\
\hline
\end{tabular}

It should be mentioned that the total water flow and pressure difference in the network will grow. It means that more powerful pumps should be used. Electricity consumption will grow, but the heat savings will be bigger than the increase of pumping cost. Besides, in case of Tallinn, most of the pipes are oversized and the growth of pressure difference is not so rapid.

\section{Heat production}

\section{Model description}

The model of the current situation was built using the EnergyPro software. The components included in this model are shown in Table III. The model consists of three sites. Site 1 includes 2 boiler houses operated during the heating season and a heat consumer. Site 2 includes a heat consumer, which is supplied by the heat produced in Site 1 and Site 3. Site 3 includes 2 energy units: the Tallinn CHPP where heat and electricity are cogenerated and Iru Plant where only two boilers are operated with no electricity generation. Besides, a heat consumer is included in Site 3. During the summer period only the Tallinn CHPP is operated supplying heat for hot water production to the whole district heating system. During the winter period all energy units are operated while the heat produced in Sites 1 and 3 is used to cover the heat demand of these sites and supplied to Site 2 also. The description of the model components is presented in Table III.

The sites of the model are shown in Figures 2-4.

On the territory of Iru Plant a waste incineration plant is planned to be built where electricity and heat will be generated from the municipal waste (Site 3). To forecast the possible operating process, two scenarios were simulated, with and without a new incineration unit.

The future changes in Site 3 are shown in Figure 5.

Data about the new unit are presented further.
TABLE III

COMPONENTS OF THE TALLINN DH MODEL

\begin{tabular}{|c|c|c|}
\hline \multicolumn{3}{|l|}{ Site 1} \\
\hline \multirow[t]{3}{*}{$\begin{array}{l}\text { Heat } \\
\text { sources }\end{array}$} & $\begin{array}{l}\text { Mustamäe boiler } \\
\text { house }\end{array}$ & $\begin{array}{l}\text { Natural gas, heat capacity } 100 \mathrm{MW} \text {, fuel } \\
\text { input } 106 \text {, working time, } 15 / 09-15 / 05\end{array}$ \\
\hline & $\begin{array}{l}\text { Kadaka boiler } \\
\text { house }\end{array}$ & $\begin{array}{l}\text { Natural gas, heat capacity } 129 \mathrm{MW} \text {, fuel } \\
\text { input } 138 \text {, working time, } 15 / 09-15 / 05\end{array}$ \\
\hline & Site 2 & $\begin{array}{l}\text { When the boiler houses in Site } 1 \text { are } \\
\text { shut down, heat is supplied via Site } 2\end{array}$ \\
\hline \multirow[t]{2}{*}{ Heat load } & $\begin{array}{l}\text { Demand in } \\
\text { Mustamäe } \\
\text { District }\end{array}$ & $\begin{array}{l}\text { Annual heat demand is } 693 \mathrm{GWh}, 11 \% \\
\text { of the demand is hot water heating load, } \\
89 \% \text { of the demand depends linearly on } \\
\text { ambient temperature during the heating } \\
\text { period. The data on the ambient } \\
\text { temperature in Tallinn for } 2010 \text { were } \\
\text { used for simulation }\end{array}$ \\
\hline & Site 2 & $\begin{array}{l}\text { During the heating period the heat } \\
\text { produced in Mustamäe and Kadaka } \\
\text { boiler houses is supplied to Site } 2\end{array}$ \\
\hline \multicolumn{3}{|l|}{ Site 2} \\
\hline \multirow[t]{2}{*}{$\begin{array}{l}\text { Heat } \\
\text { sources }\end{array}$} & Site 1 & $\begin{array}{l}\text { Heat produced in Site } 1 \text { (by Mustamäe } \\
\text { and Kadaka boiler houses) during the } \\
\text { heating season is supplied to Site } 2\end{array}$ \\
\hline & Site 3 & $\begin{array}{l}\text { Heat produced in Site } 3 \text { (by the Tallinn } \\
\text { CHPP and Iru Plant) during the heating } \\
\text { season and in summer supplied to Site } 2\end{array}$ \\
\hline \multirow[t]{2}{*}{ Heat load } & $\begin{array}{l}\text { Demand } \\
\text { in Kesklinna } \\
\text { District }\end{array}$ & $\begin{array}{l}\text { Annual heat demand is } 380 \mathrm{GWh}, 11 \% \\
\text { of the demand is hot water heating load } \\
\text { and } 89 \% \text { of the demand has a linear } \\
\text { dependence on the ambient temperature } \\
\text { during the heating period. The data on } \\
\text { the ambient temperature in Tallinn for } \\
2010 \text { were used for the simulation. }\end{array}$ \\
\hline & Site 1 & $\begin{array}{l}\text { During the summer period, the heat } \\
\text { supplied from Site } 3 \text { is distributed in } \\
\text { Site } 1\end{array}$ \\
\hline \multicolumn{3}{|l|}{ Site 3} \\
\hline \multirow[t]{2}{*}{$\begin{array}{l}\text { Heat } \\
\text { sources }\end{array}$} & Tallinn CHPP & $\begin{array}{l}\text { Wood, heat capacity } 65 \mathrm{MW} \text {, electrical } \\
\text { capacity } 25 \mathrm{MW} \text {, fuel input } 125 \text {, } \\
\text { working time year-round supply }\end{array}$ \\
\hline & Iru Plant & Natural gas, $353 \mathrm{MW}$ \\
\hline \multirow[t]{2}{*}{ Heat load } & $\begin{array}{l}\text { Demand in } \\
\text { Lasnamäe District }\end{array}$ & $\begin{array}{l}\text { Annual heat demand is } 561 \mathrm{GWh}, 11 \% \\
\text { of the demand is hot water heating load } \\
\text { and } 89 \% \text { of the demand has a linear } \\
\text { dependence on the ambient temperature } \\
\text { during the heating period. The data on } \\
\text { the ambient temperature in Tallinn for } \\
2010 \text { were used for simulation. }\end{array}$ \\
\hline & Site 2 & $\begin{array}{l}\text { During the heating period and in } \\
\text { summer the heat produced in Tallinn } \\
\text { CHPP and Iru Plant is supplied to Site 2, } \\
\text { during the summer time when other heat } \\
\text { generation units are shut down, the heat } \\
\text { is supplied via Site } 2 \text { to Site } 3\end{array}$ \\
\hline \multicolumn{3}{|c|}{ Transmissions } \\
\hline $\begin{array}{l}\text { Transmis } \\
\text { sion } 1\end{array}$ & \multicolumn{2}{|c|}{$\begin{array}{l}\text { Heat from Site } 1 \text { can be supplied to Site } 2 \text { and from Site } 2 \text { to } \\
\text { Site } 1 \text {, the maximum capacity } 200 \mathrm{MW} \text {, loss } 10 \%\end{array}$} \\
\hline $\begin{array}{l}\text { Transmis } \\
\text { sion } 2\end{array}$ & \multicolumn{2}{|c|}{$\begin{array}{l}\text { Heat from Site } 3 \text { can be supplied to Site } 2 \text { and from Site } 2 \text { to } \\
\text { Site } 3 \text {, the maximum capacity } 173 \text { MW, loss } 10 \%\end{array}$} \\
\hline
\end{tabular}




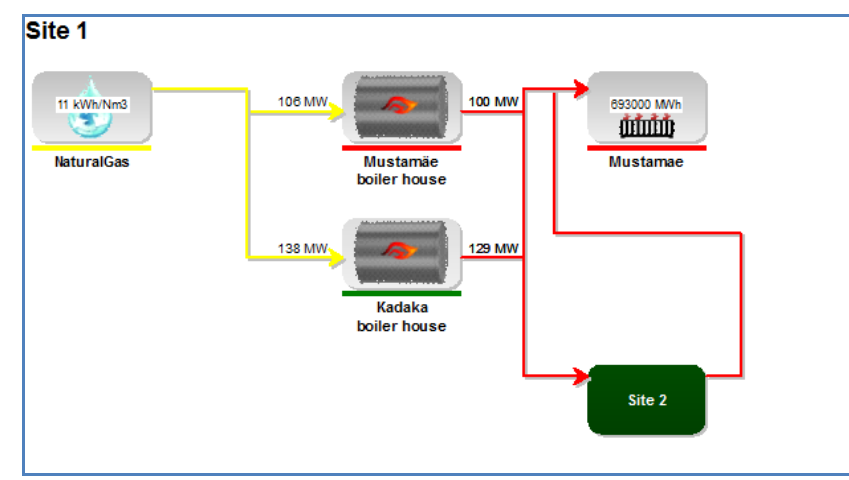

Fig. 2. Model of Tallinn district heating system, Site 1

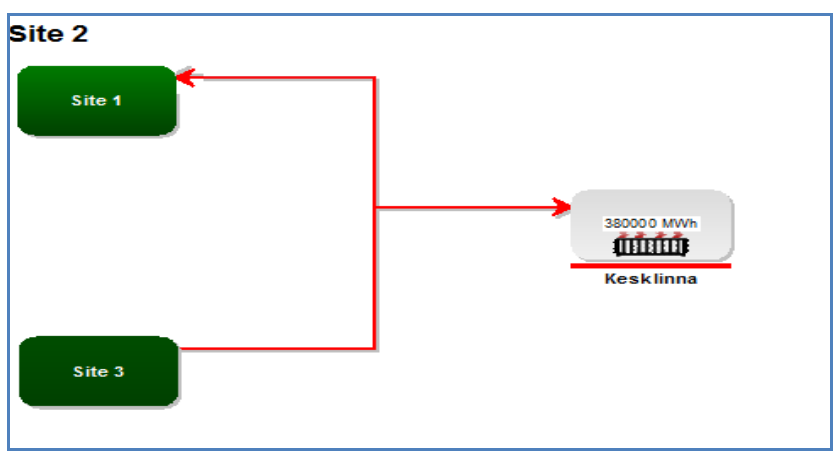

Fig. 3. Model of Tallinn district heating system, Site 2

\section{Input data and assumptions}

Actual data on operating heating plants were used (Table III). For the heat demand simulation, it was assumed that $89 \%$ of heat demand is linearly dependent on ambient temperatures and $11 \%$ of the demand goes to cover hot water consumption. The average annual heat demand for the last three years (2008-2010), which is $1691 \mathrm{GWh}$, was taken as a basis for the calculation

As it was mentioned above, the simulation was made for two scenarios: with and without a new waste incineration plant. The data on the waste incineration plant used in the simulation are shown in Table IV.

TABLE IV

PARAMETERS OF WASTE INCINERATION Plant [19, 20]

\begin{tabular}{|l|l|}
\hline \multicolumn{2}{|l|}{ Waste incineration plant } \\
\hline Fuel & Waste \\
\hline Heat value of fuel & $10.5 \mathrm{MJ} / \mathrm{kg}$ \\
\hline Fuel input & $80.5 \mathrm{MW}$ \\
\hline Heat capacity & $50 \mathrm{MW}$ \\
\hline Electricity capacity & $17 \mathrm{MW}$ \\
\hline
\end{tabular}

For simulating the operation, one more indicator should be included. This indicator is the priority of unit operation. The assumed priorities according to the operation strategy are shown in Table V.

In both cases the highest priority is the Tallinn CHPP. Tallinn CHPP is a plant, which was launched in cogeneration mode in 2009. Wood chips are used as a fuel for electricity and heat production.

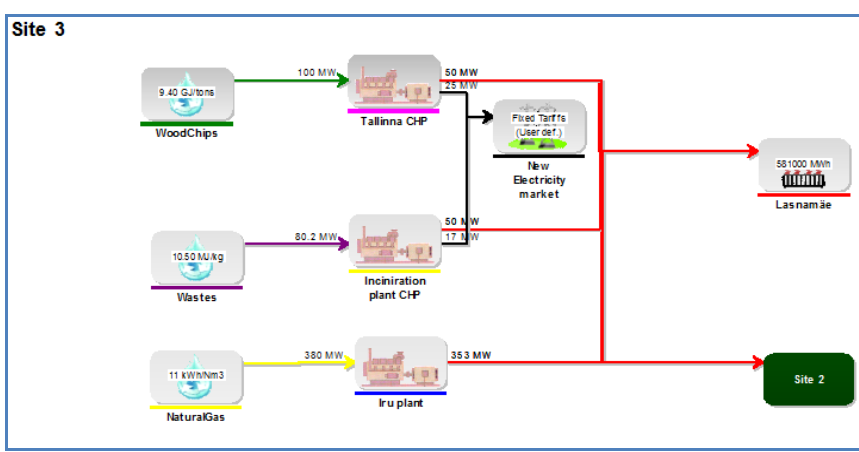

Fig. 5. Model of Tallinn district heating system, Site 3 (with an incineration plant)

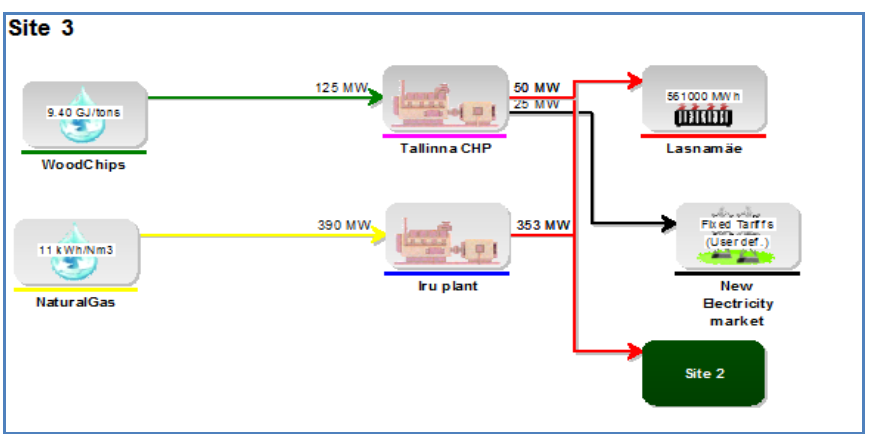

Fig. 4. Model of Tallinn district heating system, Site 3

The Mustamäe and Kadaka boilers have almost the same parameters and that is why they have the same priority. The Iru Plant is owned by another company and will be bought from the owner.

When the incineration plant will start to operate, its priority will be very high, because it is an environmentally friendly and energy efficient technology.

TABLE V

OPERATION STRATEGY PRIORITIES

\begin{tabular}{|l|l|l|l|}
\hline Unit & $\begin{array}{l}\text { Priority } \\
\text { (current } \\
\text { situation) }\end{array}$ & $\begin{array}{l}\text { Priority } \\
\text { (with the } \\
\text { incineration } \\
\text { plant) }\end{array}$ & $\begin{array}{l}\text { Partial } \\
\text { load } \\
\text { allowed }\end{array}$ \\
\hline Tallinn CHPP & 1 & 1 & yes \\
\hline Iru Plant (boiler) & 4 & 4 & yes \\
\hline Mustamäe boiler & 2 & 3 & yes \\
\hline Kadaka boiler & 2 & 3 & yes \\
\hline $\begin{array}{l}\text { Incineration plant } \\
\text { (CHP) }\end{array}$ & - & 2 & yes \\
\hline
\end{tabular}

$\underline{\text { Results }}$

The results of simulation are shown in Table VI. The simulation showed that in case the incineration plant is used additionally, electricity generation will increase by $43 \%$. The consumption of fossil fuel - natural gas will decrease by $20 \%$.

The year-round operation of the system is shown graphically in Figure 6. Figure 6 shows that Tallinn CHPP operates all year round. The Mustamäe boiler house operates throughout the heating period, but the Kadaka boiler house and Iru Plant are used for peak loads.

Figure 7 shows the operation forecast for the second scenario when the incineration plant is added. The Tallinn 
CHPP operates all year round. The incineration plant works at full load throughout the heating period. The Mustamäe boiler house operates during the whole heating period, but at partial load. The Kadaka boiler house and Iru Plant work less than in the first scenario.

TABLE VI

SiMUlation RESUltS FOR HEAT PRODUCTION

\begin{tabular}{|l|l|l|}
\hline Indicators & $\begin{array}{l}\text { Without the } \\
\text { incineration } \\
\text { plant }\end{array}$ & $\begin{array}{l}\text { With } \\
\text { incineration } \\
\text { plant }\end{array}$ \\
\hline Heat production (GWh) & $\mathbf{1 , 8 5 4 . 6 0}$ & $\mathbf{1 , 8 5 7 . 3 0}$ \\
\hline Tallinn CHPP & 438.00 & 438.00 \\
\hline Incineration plant CHP & & 278.40 \\
\hline $\begin{array}{l}\text { Mustamäe } \\
\text { boiler house }\end{array}$ & 711.00 & 667.10 \\
\hline Kadaka boiler house & 394.40 & 354.70 \\
\hline Iru Plant & 311.20 & 119.10 \\
\hline Electricity production (GWh) & $\mathbf{2 1 9 . 0 0}$ & $\mathbf{3 1 3 . 6 0}$ \\
\hline Tallinn CHPP & 219.00 & 219.00 \\
\hline Incineration plant CHP & & 94.66 \\
\hline Fuel consumption (GWh) & $\mathbf{2 , 3 1 4 . 0 0}$ & $\mathbf{2 , 4 6 7 . 4 0}$ \\
\hline Natural gas & $1,438.00$ & $1,144.80$ \\
\hline Wood & 876.00 & 876.00 \\
\hline Waste & & 446.60 \\
\hline Working hours & & 8760 \\
\hline Tallinn CHPP & 8760 & 5568 \\
\hline Incineration plant CHP & & 5616 \\
\hline Mustamäe \\
boiler house & 5616 & 4008 \\
\hline $\begin{array}{l}\text { Kadaka } \\
\text { boiler house }\end{array}$ & 5064 & 2544 \\
\hline Iru Plant & 5136 & \\
\hline
\end{tabular}

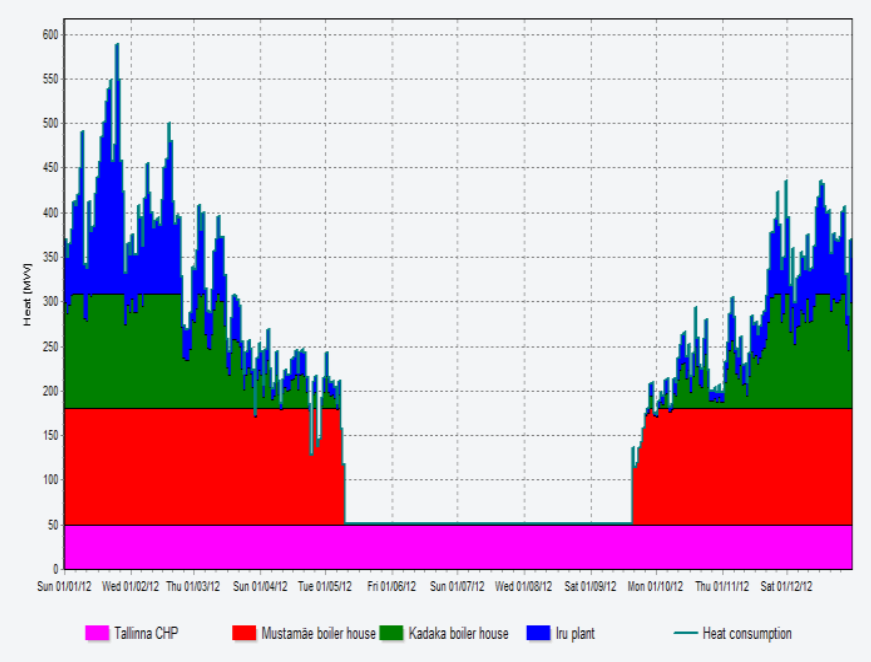

Fig. 6. Heat load of Tallinn District Heating Network. Simulation of the current situation

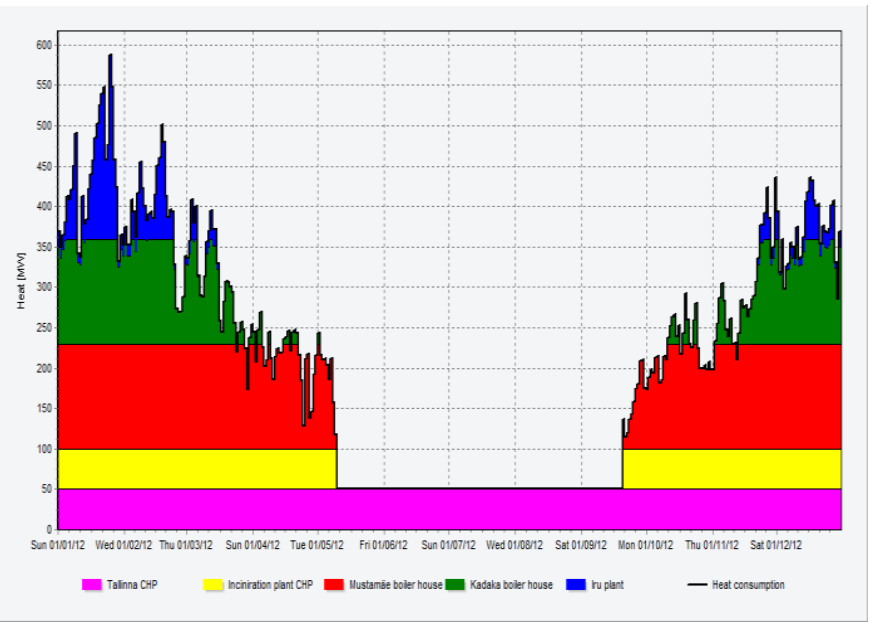

Fig.7. Heat load of Tallinn District Heating Network. Simulation of the scenario with an additional waste incineration plant

\section{CONCLUSiOnS}

The reliability and cost-efficiency of district heating depends on the efficiency of its operation. In this paper a methodology for the assessment and efficiency increasing of heat production and distribution was offered.

As a case study, the Tallinn district heating system was analyzed. The Tallinn district heating system includes 4 heat plants, which cover the heat demand in 3 districts. For the evaluation of district heating network, a model was created using the TERMIS software. For the heat loss analysis and hydraulic analysis, four different scenarios were simulated: the current situation, decreased maximum flow temperature by $15^{\circ} \mathrm{C}$, decreased consumption by $20 \%$ and decreased temperature by $20^{\circ} \mathrm{C}$ with the decreased consumption by $20 \%$. As a result, the decrease of relative heat loss by $23.2 \mathrm{GWh}$ during the heating season compared to the current situation was gained.

For the evaluation of energy production, a model was created using the EnergyPro software. The system was split into three sites. This model was used for the simulation of two scenarios: the current situation and the case where a new incineration cogeneration plant will be installed. The actual data for the last years were used for the simulation. The results of simulation showed that, according to the current situation, the cogeneration plant should work all year round, the boiler houses should operate during the heating period and the Iru Plant boiler should be used only for the peak heat load. In case when the incineration plant is added, it can operate at full load during more than 5500 hours per year. Heat generation in this plant will decrease the consumption of natural gas by $20 \%$. The amount of electricity production in the cogeneration mode will increase by $43 \%$. The evaluation of district heating demand was made mainly from the technical point of view.

The effective operation of the district heating system, both at the stage of heat generation and heat distribution, can reduce the cost and price of heat supplied to the consumers. It can become an important factor for increasing the number of district heating consumers and demand for the heat load, which in turn will allow installing new cogeneration plants, using renewable energy sources and heat pump technologies. 


\section{ACKNOWLEDGMENTS}

This work has been partly supported by the European Social Fund within the researcher mobility program MOBILITAS (2008-2015), MJD10 and DoRa program.

\section{REFERENCES}

1. Communication from the Commission to the European Parliament, the Council, the European Economic and Social Committee and the Committee of the Regions. Energy 2020. A strategy for competitive, sustainable and secure energy. Available at <http://www.energy.eu/directives/com-2010-0639.pdf >>. [Accessed 01.12.2011].

2. Rezaie B, Rosen MA. District heating and cooling: Review of technology and potential enhancements. Applied Energy 2012; 93: 2-10.

3. Hlebnikov A., Volkova A., Džuba O., Poobus A., Kask U. Damages of the Tallinn District Heating Networks and indicative parameters for an estimation of the networks general condition In:Proceedings of 12th International Symposium on District Heating and Cooling, Estonia, Tallinn, 5.-7. September, 2010. - 277.-282. pp

4. Vallios I., Tsoutsos T., Papadakis G. Design of biomass district heating systems. Biomass and Bioenergy 2009; 33(4): 659-678.

5. Difs K., Wetterlund E., Trygg L., Söderström M. Biomass gasification opportunities in a district heating system. Biomass and Bioenergy 2010, 34(5): 637-651.

6. Holmgren K., Gebremedhin A. Modelling a district heating system: Introduction of waste incineration, policy instruments and co-operation with an industry. Energy Policy 2004; 32(16): 1807-1817.

7. Hepbasli A. A review on energetic, exergetic and exergoeconomic aspects of geothermal district heating systems (GDHSs) Energy Conversion and Management 2010; 51(10): 2041-2061.

8. Lund H., Möller B., Mathiesen B.V., Dyrelund A. The role of district heating in future renewable energy systems. Energy 2010; 35(3): 13811390.

9. Tveit T.-M., Savola T., Gebremedhin A., Fogelholm C.-J. Multiperiod MINLP model for optimising operation and structural changes to CHP plants in district heating networks with long-term thermal storage. Energy Conversion and Management 2009; 50(3): 639-647.

10. Volkova A., Hlebnikov A., Siirde A. Methodology for defining of eligible capacity for wood fuel based cogeneration plants in small towns in Estonia. Journal of Energy and Power Engineering: 2011; 5(6): 481 489.

11. Barelli L., Bidini G., Pinchi E.M. Implementation of a cogenerative district heating system: Dimensioning of the production plant Energy and Buildings: 2007; 39(6): 658-664.

12. Kelly S., Pollitt M. An assessment of the present and future opportunities for combined heat and power with district heating (CHPDH) in the United Kingdom Energy Policy 2010, 38(11):6936-6945

13. TERMIS Operation User Guide, 7-Technologies, 2011.

14. Tol H.I., Svendsen S. Improving the dimensioning of piping networks and network layouts in low-energy district heating systems connected to low-energy buildings: A case study in Roskilde, Denmark, Energy 2012 38(1): 276-290.

15. Li H., Dalla Rosa A., Svendsen S. Design of low temperature district heating network with supply water recirculation, In: Proceedings of 12th International Symposium on District Heating and Cooling, Estonia, Tallinn, 5.-7. September, 2010: 73-80

16. Hinojosa L.R., Day A.R., Maidment G.G., Dunham C. A Comparison of combined heat and power feasibility models, Applied Thermal Engineering 2007; 27 (13): 2166-2172.

17. User's Guide EnergyPRO, EMD, 2008

18. Tallina Küte www.soojus.ee.

19. Report of environmental assessment. Waste use for combined heat and power production on the territory of Iru Plant. (Kütusena jäätmeid kasutava soojus- ja elektrienergia koostootmisploki rajamine Iru elektrijaama territooriumile, $\mathrm{KMH}$ hindamise aruanne), EestiEnergia 2007

20. IRU WtE - technical overview Jäätme energia plokk WTE, 2010, CNIM.
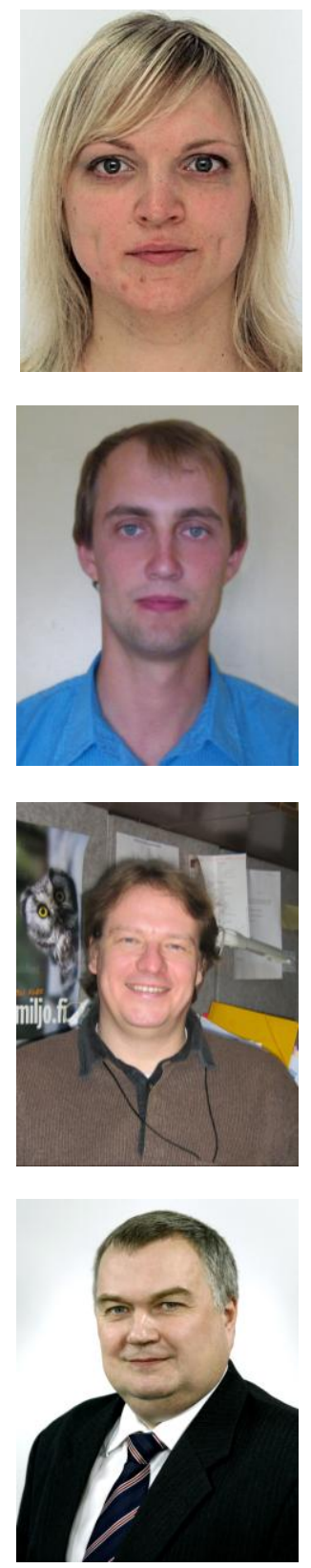

Anna Volkova, Dr.sc. ing., has been post-doc researcher in the Department of Thermal Engineering, Tallinn University of Technology since 2009. Since 2003 she has been working in Riga Technical University. Her doctor PhD thesis was defended in the Riga Technical University in 2008. The main research topics are cogeneration, energy efficiency, district heating. A. Volkova is co-author of about 30 scientific publications.

Address: Kopli 116, Tallinn, 11712, Estonia

E-mail: anna.volkova@ttu.ee

Vladislav Mashatin, Mg.sc., Tallinn University of Technology, Department of Thermal Engineering $\mathrm{He}$ has a bachelor (2009) and master degree (2011) in thermal power engineering and he is a $\mathrm{PhD}$ student of the Department of Thermal Engineering of the Tallinn University of Technology. The main research interests are energy efficiency, district heating, thermal storage, cogeneration. V.Mashatin regularly participates in local and international conferences

E-mail: shatrey@gmail.com

Aleksandr Hlebnikov, $\mathrm{PhD}$, has a diploma of thermal engineering (1994), master of science degree in thermal engineering (2000), $\mathrm{PhD}$ in engineering (2011). He is a part of academic staff in the Department of Thermal Engineering, Tallinn University of Technology, starting from 1994 and currently works as a docent. The main research area is district heating systems and energy efficiency. A.Hlebnikov is co-author of about 25 scientific publications.

E-mail: aleksandr.hlebnikov@ttu.ee

Andres Siirde, $\mathrm{PhD}$, professor, Head of Chair of Thermal Power Equipment, the Department of Thermal Engineering of theTallinn University of Technology. A.Siirde has been a part of academic staff of TUT since 1984. He has a Industrial Thermal Power Engineer Diploma (1980) and doctoral degree (1984). The main research areas are oil shale, cogeneration, SEG emissions, energy efficiency. A.Siirde is author of about 60 publications.

E-mail: andres.siirde@ttu.ee 